\title{
Public Relations in Organizations in Student View: Accumulator of Management Tools or Formation of Partnership and Friendly Relations
}

\author{
Vagiz G. Gimaliev ${ }^{1}$, Alexey I. Prokopyev ${ }^{2}$, Valentin P. Vershinin ${ }^{3}$, Marina E. Ivanova ${ }^{4}$, \\ Gulfairuz G. Erkibaeva ${ }^{5}$, Jhanna I. Aytuganova ${ }^{6}$, Natalya S. Alexandrova ${ }^{7}$ \\ ${ }^{1}$ Department of Foreign Languages №2, Chuvash State University, Cheboksary, Russian Federation \\ ${ }^{2}$ Department of State and Legal Disciplines, Plekhanov Russian University of Economics, Moscow, Russian Federation \\ Department of Economics and Management, Moscow Psychological and Social University, Moscow, Russian Federation \\ ${ }^{4}$ Department of Pedagogy, Moscow Region State University, Moscow, Russian Federation \\ ${ }^{5}$ Department of World Languages, Khoja Akhmet Yassawi International Kazakh-Turkish University, Turkestan, Kazakhstan. \\ ${ }^{6}$ Department of Foreign Languages, Kazan State Power Engineering University, Kazan, Russian Federation \\ ${ }^{7}$ Department of Pedagogy and Methods of Preschool and Primary Education, Vyatka State University, Kirov, Russian Federation
}

Received: 18/12/2020

Accepted: 19/03/2020

Published: 20/02/2020

\begin{abstract}
The relevance of this article is the need to study the students' understanding of public relations as a means of management. The experience of countries with a developed social sphere shows that the use of public relations in the management of social work institutions can improve the social status of social services, form a positive public opinion and, as a result, ensure the social effectiveness of services provided. The purpose of the research is to analyze students' perceptions of the essence of public relations as a means of managing social services in the external environment. Research methods: as a research method, we used a questionnaire survey, which allows us to qualitatively investigate public relations in the organization through the eyes of students. Results of the research: the article considers the students' views on the means of managing social services in the external environment, and reveals the role of public relations in the management of social services in the external environment in the representation of students. The novelty and originality of the research consists in the analysis of public relations as a means of management in the external environment in relation to the activities of social protection institutions in the representation of students. It is revealed that, in the view of students, public relations accumulate management tools and include: the use of various forms of communication aimed at identifying common views or interests of different groups; they contribute to the formation of partnership and friendly relations between the social service, clients and the General public; ensure the achievement of mutual understanding based on truth and full public awareness and, ultimately, form a positive public opinion and a favorable image for the social service. The essential aspects, specific features, structural and functional features and opportunities of public relations as a means of managing social services in the external environment are highlighted in the students' view. It is determined that in the students' views, the management of the social service does not have a well-thought-out concept of organizing public relations, which leads to ineffective management of the social service in the external environment and is used in social work spontaneously. Practical significance: the data obtained in this work can be used in social psychology, Economics, advertising psychology, management psychology, as well as for further theoretical development of this issue.
\end{abstract}

Keywords: Student youth, Public relations, Vision, Management

\section{Introduction}

Currently, there are many tools and methods available in the Arsenal of the social service Manager for planning, organizing, motivating and controlling the internal environment of the organization in response to external changes. The only social service that can survive and function effectively in a rapidly changing environment is one that will adapt to the environment in time and possibly find ways to influence it using special management tools [1]. Social service as an open system cannot function fully without cooperation and interaction with the external environment of the organization, since the success of social service activities depends on the forces of the external environment, which determine the General rules of the game, so they must be taken into account and used. The external environment of a social service is an environment that encompasses a large number of different factors that, in one way or another, can affect the functioning of the social service both in the current period and in the future $[2,3]$. Social service management in the external environment is understood as the process of purposeful influence of the management entity in the person of the governing body or Manager on the object of management in the person of the social service that provides social services, taking into account external factors that affect the functioning of the social service [4 - 9]. The assessment of environmental components should be based on the allocation of funds (i.e., those components that the organization can use to achieve its own goals) and conditions (components of the external

Corresponding author: Vagiz G. Gimaliev, PhD in Philology, Associate Professor of the Department of Foreign Languages №2, Chuvash State University, Cheboksary, Russian Federation. E-mail: vagizgimaliev@mail.ru 
environment that the organization cannot use to achieve goals). By ranking other social institutions surrounding the social service (social movements, social institutions, state institutions), the management of the social service will be able to navigate in constantly changing situations that arise in the external environment, and find optimal ways to achieve organizational goals [10 -13]. Public relations is a management tool that uses various forms of communication aimed at identifying common views or interests of different groups, promotes the formation of partnership and friendly relations between the social service, clients and the General public, ensures the achievement of mutual understanding based on truth and full public awareness, and ultimately forms a positive public opinion and a favorable image for the social service [1419] Becoming a subject of management activity, having broad economic independence in its production and economic activities, the social service should form a management system that could provide them with a sufficient degree of functioning efficiency, competitiveness and a stable position in the market of social services. This task is carried out by using appropriate management tools in management practice [20-22].

Thus, in the management of social services, it is important to take into account all the factors of the external environment of the organization and build management strategies accordingly [23-26]. If there is a change in the direct impact factors, the social service can respond in two ways: either to initiate a policy of active adaptation, or to implement a policy of counteraction. The social service has to adapt its internal variables - goals, tasks, structure, technology, organization personnel, etc. - to the factors of indirect impact. Public relations is a comprehensive tool for managing social services in the external environment and actualizes all other management tools, including social communication, image, social partnership and positioning. In this regard, it is necessary to describe the role of public relations in the management of social services in the external environment in more detail.

\section{Materials and Methods}

The study included a number of stages. At the first stage, a survey of Humanities students and students studying at economic faculties was conducted who were interning at the center for social services in order to identify ideas about the current state of using public relations as a means of managing the center for social services of citizens. The sample was targeted. When conducting a questionnaire survey, it was assumed that the process of registration reveals the subjective views, opinions and assessments of students, which are subject to fluctuations, the effects of the survey conditions and other circumstances. To minimize data distortion associated with these factors, the survey was conducted in a short time

The questionnaire included three sections. The first section was devoted to introducing students to the concept of public relations. The second section of the questionnaire included an assessment of the practice of using the leading areas of public relations when working with clients, commercial structures, and media structures. The third section covered the issues of public relations in working with sponsors. The fourth section of the questionnaire concerned General information about the Respondent.

In the pilot study, the following results were found.

To the question: Do you have any idea about public relations in the management of the social service center? The opinion of students was divided as follows: $61 \%$ of students of Humanities answered in the affirmative, $23 \%$ of respondents were confused with the answer, and $16 \%$ did not know what it was. The answers of students studying at the faculty of Economics are somewhat compared and distributed as follows:
$71 \%$ said that they knew about the organization of public relations in the organization's activities, $81 \%$ were difficult to answer, and $11 \%$ had no idea about public relations in the organizations' activities.

\section{Results}

When answering a question: What, in Your opinion, is the activities of public relations?, the answers were distributed as follows: $62 \%$ of Humanities students indicated the formation of a positive image of the center of social service of the institution in the eyes of the public, $25 \%$ pointed to the propaganda activities of social service centers and $13 \%$ to the advertising social services. Among students of the faculty of Economics, only $39 \%$ indicated the formation of a positive image of the institution in the eyes of the public, $58 \%$ of respondents noted the promotion of the social service center, and $3 \%$ of students noted the advertising of social services as their main activity. As you can see, the opinions of students of Humanities and students of the faculty of Economics differ radically. This indicates that these students have different information about the management activities of social service centers' administration.

The next question in the questionnaire was to find out what areas of public relations work in the social service was organized in. Respondents were asked to evaluate the activities of the center's management in four areas: working with clients, working with a commercial structure, working with government authorities, and working with the media. As an additional option, respondents could indicate a different line of work that they believed was taking place in their social service. The answers were as follows. Speaking about working with clients, Humanities students $(81 \%)$ noted that this type of activity was carried out regularly, only $9 \%$ of respondents chose the option from time to time, and $10 \%$ found it difficult to answer. According to students of the faculty of Economics, working with clients was carried out regularly in $100 \%$ of cases. Describing the work of the social service center with the mass media, $39 \%$ of students of Humanities noted that it was rarely carried out; the answer: it was carried out occasionally, $33 \%$ of respondents chose; $20 \%$ noted that work in this area was carried out regularly; $8 \%$ found it difficult to answer. The responses of students of the faculty of Economics were distributed as follows: $37 \%$ found it difficult to answer; $19 \%$ indicated that work in this area was carried out on a case-bycase basis; $10 \%$ of respondents noted the answer - rarely, and $34 \%$ believed that work with the media was carried out constantly. The respondents did not identify any other areas of public relations. Summing up the above-mentioned, one can sum up some results. Evaluating the work of the social service center for public relations, the majority of students $(89 \%)$ identified such a direction as working with clients. A similar picture could be seen when evaluating interaction with state authorities and state structures. Evaluating the work with a commercial structure, the majority of students said that such activities were carried out in the social service center rarely $(48 \%)$ or not at all (52\% of respondents). However, among students of the Humanities, the percentage of those who found it difficult to answer was quite large. This fact suggests that students in the Humanities to a lesser extent had information about this area of organization of public relations in social service.

Thus, speaking about the contacts of the social service center with the media, the students unanimously noted that such work, in their opinion, was carried out on a case-by-case basis. The results obtained allow us to state that the work on public relations in the social service center was narrowly focused, 
directly related to the main professional activities of employees and the management apparatus.

The next section of the study was devoted to finding out what forms of public relations organization were used, in the opinion of students, in the management of social services in each of the indicated areas. The results were distributed as follows. When working with clients, $68 \%$ of Humanities students noted holidays and special events, $21 \%$ of students indicated articles in Newspapers and $11 \%$ found it difficult to answer. The opinion of students of the faculty of Economics was distributed as follows: $72 \%$ noted holiday and festive events, $10 \%$ pointed to publications in Newspapers and $12 \%$ were difficult to answer. Thus, the opinions of students on this issue actually coincide. The study showed that working with clients special attention was paid to working with real clients (72\%); the social service center paid attention to working with potential clients, according to $21 \%$ of respondents, and $7 \%$ of the surveyed Humanities students noted working with a reference group for clients. The opinion of students of the faculty of Economics was distributed as follows: $81 \%$ noted working with real clients; $9 \%$ indicated working with potential clients and $10 \%$ noted a reference group for clients.

In this regard, the students were asked: Does the social service where they were trained have a special plan for organizing public relations? Students' responses were distributed as follows: $71 \%$ did not know about the existence of such a plan; $17 \%$ of students believed that there was no such plan; $12 \%$ believed that there was such a plan. The received answers allowed us to state that there was no purposeful activity on organizing public relations in the social service center, where students were interned. To the question: How often is information given to the press about the activities of the social service in which they were trained? The respondents' opinions were distributed as follows: the first place - the answer was not given at all; the second place was taken by the answer: once a year, the third place was taken by the answer: once every six months. Answer - once every three months no one had chosen. These responses indicated that in the students' views, the management of the social service did not have a well-thoughtout concept of organizing public relations, which led to ineffective management of the social service in the external environment.

At the end of the survey, the respondents were asked to evaluate the level of public relations organization in the social service center where they had practice, in General. For this purpose, we asked the respondents: what level do they think was the use of forms and methods of public relations in the work of the social service in which they were practiced? The results of the responses were distributed as follows: students of Humanities in the first place put the average level; the second place was taken by the answer - high and low level was in third place. Students of the faculty of Economics believed the same. An important feature of properly organized PR is that this work should be aimed not so much at short-term results, but at achieving long-term goals.

The diversity of opinions of students who were interning in social service centers required an assessment of the state of public relations organization as a means of management in the external environment by the administration of these centers. We were interested in the management's opinion on how public relations were used in the management of the social service center, and how the management's activities in this area were organized. In connection with the above-mentioned, a survey was conducted between the Director of the social service center and the heads of the center's departments. The sample was constant by nature. The survey shows that the priority in public relations is working with real clients. Work with potential clients and reference groups for clients is practically not carried out, everything is limited to accepting applications for social services. This situation is explained, first, by the lack of personnel and the reluctance of people to contact the social service. Specialists of the center are aimed primarily at meeting the standards for the reception of citizens, completed cases depending on the direction of work, while the heads of structural divisions coordinate the work and monitor the completion of cases. The next section of the survey concerned the use of forms and methods of organizing public relations in the management of social services. The results of the responses showed that they were intermittent and haphazard, and most employees were not aware of the possible use of forms and methods of public relations. Feedback from the population was provided, but mostly it was complaints or thanks and congratulations on holidays. Managers of structural divisions of social service centers were not well aware of the forms and methods of organizing public relations and did not use them in their practical activities. The next section of the interview concerned working with a commercial structure. According to the study, this work is being carried out, but it is at a low level. Almost all respondents admit that the work with the commercial structure is carried out, but it is unstable and not clearly structured. As for the organization of public relations with the mass media (radio, Newspapers, television), the situation is somewhat different. Clarification of the nature of interaction between social services and the media was not an unimportant issue. Relations with the media are an essential component of public relations. Public opinion is mainly formed by what people read in the press, hear on the radio or see on television, so cooperation with the media should be given special attention. Work with the state structure is carried out systematically, but it is not always possible to lobby the interests of the social service. During the survey, we were interested in the question: How does public relations affect the activities of the social service? Is public relations a means of managing social services in the external environment? Respondents' opinions agreed that public relations really had a positive impact on the work of the center. Therefore, the study showed that Department managers considered it important to organize public relations in social service centers, but unfortunately, this activity in the management of social services was poorly organized and was random. Thus, students' perceptions of the work of public relations in social service centers largely coincide with the opinion of the centers' management.

\section{Discussions}

In modern conditions, public relations as a means of managing social services in the external environment should be aimed at fully explaining to the public the existing socioeconomic problems, creating a positive image of the institution of social work, ensuring a favorable social atmosphere in the external environment in society, for the implementation of the social programs provided. It is clear from the research that the majority of managers of the social service center believe that the organization of public relations in the management of their service is at an average level. Students also note that this is a whole direction of management activity, which is not yet widely studied and is used in social work spontaneously. Therefore, some shortcomings in the work are obvious. In particular, during the survey, the heads of structural departments of the social service center expressed a number of wishes and suggestions for improving this work: when organizing public relations with clients, it is necessary to attract potential clients and organize work with a reference group for clients; for organizing public relations with sponsors, it is 
important to focus on working with sponsors. Research is needed to find a potential sponsor. It is necessary to determine which characteristics of the event held in social service centers correspond to the interests of potential sponsors. Working with a sponsor means constant communication. The ultimate aerobatics of working with a sponsor is when the sponsor is involved in the work of the social service, is constantly interested in what is happening, and becomes indifferent to all subsequent events. It is quite difficult to find a sponsor willing to pay for even part of the event. You must regularly send emails to sponsors describing the event, conduct telephone conversations, as well as organize personal meetings - the key to establishing the necessary contacts. It is necessary to ensure constant work with the media. To organize all this work, respondents consider it necessary to allocate a staff unit that will be engaged in organizing public relations in social service centers. From the research conducted, it becomes clear that, in the view of students, the social service tries to apply public relations in its management activities; however, almost all attention is paid to real clients of the social service, which indicates a large share of the audience, which is not covered.

\section{Conclusion}

Summarizing the above-mentioned, it should be noted that the experience of countries with a developed social sphere shows that the use of public relations in the management of social work institutions can improve the social status of social services, form a positive public opinion and, as a result, ensure the social effectiveness of services provided.

Meanwhile, practice shows that not all social services have the technology to organize public relations. Many managers of social services underestimate the role of public relations in the management of the organization, do not know the technology of establishing contacts in the external environment, and do not know the forms and methods of public relations. Ultimately, this reduces the effectiveness of the social service as a whole, reduces its status in society and does not contribute to the formation of a positive public opinion. As a result, the activities of the social work institution are poorly covered in the mass media, and the population is poorly informed about the activities of the social service. The public is not well aware of the organization's innovations and operating procedures, which complicates the work of the institution. Ultimately, this creates a low level of public confidence in individual social institutions and, in particular, in social services. At the same time, when planning further development of social work institutions, it is necessary to take into account the current state of society. If during the Soviet period the management of social work institutions was a function of the administrative and command system and the formation of the image of the institution in public opinion did not exist, today the task of forming public relations in the management of social services in the external environment becomes one of the pressing tasks of modern management. Now, when managing social work institutions in the external environment, it is necessary to clearly understand the goals and mission of the organization, and be ready for a broad dialogue with the public.

\section{Ethical issue}

Authors are aware of, and comply with, best practice in publication ethics specifically with regard to authorship (avoidance of guest authorship), dual submission, manipulation of figures, competing interests and compliance with policies on research ethics. Authors adhere to publication requirements that submitted work is original and has not been published elsewhere in any language.

\section{Competing interests}

The authors declare that there is no conflict of interest that would prejudice the impartiality of this scientific work.

\section{Authors' contribution}

All authors of this study have a complete contribution for data collection, data analyses and manuscript writing.

\section{References}

[1] Voitenko AI, Komarov EI. Organization, management and administration in social work. Moscow: INFRA-M.2010.

[2] Frolova SS. Sociology of organization. Textbook for higher educational institutions. Moscow: Nauka.1997.

[3] Cherdymova EI, Machnev VYa. The Genesis of scientific representations about ecological, professional, and ecoprofessional consciousness. Modern problems of science and education.2016;5:268-276

[4] Burganova AA. Management theory. Moscow: INFRA M.2009.

[5] Mescon MKh, Albert M, Khedouri F. Fundamentals of management: Trans. from English. Moscow: Delo.1997.

[6] Zayats OV. Organization, administration and management in social work. Moscow: IIFRA-M.2004.

[7] Cherdymova EI, Borisova MO, Peremyshlina ES, Peshnova EI. Professional adaptation of employees as a social factor of effective organization activity. Cooperation and entrepreneurship: status, problems and prospects. Collection of scientific papers of the International conference of young scientists, postgraduates and students.2017:118-120.

[8] Machnev VYa, Cherdymova EI. The Essence of differences between eco-professional, environmental and professional training of a specialist. Current issues of human ecology: social aspects. Collection of scientific articles of participants of the International scientific and practical conference: in three volumes.2017:7-12

[9] Lomov BF, Zhuravlev AL. Psychology of management. Moscow: Znanie.1978.

[10] Zaitsev DV. Organization, management and administration in social work: textbook, second ed. updated and revised. Moscow: Publishing and trading Corporation "Dashkov and Ko".2011.

[11] Mikheev VA. Fundamentals of social partnership: theory and policy: Moscow: Examen.2001.

[12] Putilina ES, Cherdymova EI, Kurbanov RA, Belyalova AM, Shatskaya II, Kobzeva EI, Zhuravleva MV, Meleshko GS. Ecological relationships in real and virtual environments: contact points. EurAsian Journal of BioSciences Eurasia J Biosci.2019;13:1475-1480.

[13] Olkhovaya TA, Cherdymova EI, Merculova LV, Manakova OS, Sukhodolova EM, Laptev AA, Popova OV. Development features of students communicative focus. Modern Journal of Language Teaching Methods.2019;9(1):78-89.

[14] Ponomarev NF. Public Relations: socio-psychological aspects. Saint Petersburg: Peter.2008.

[15] Abramov RN. Public Relations. Moscow: Publishing house "Knorus".2012.

[16] Barezhev VA, Malkevich AA. Organizing and conducting PR campaigns. Saint Petersburg: Piter.2010.

[17] Kuznetsov VF. Public Relations: Theory and technology. Moscow: Aspect Press.2007.

[18] Kovalchuk AS. Fundamentals of image study and business communication: a textbook for University students. Fourth ed. updated and revised. Rostov on Don: Phoenix.2009.

[19] Kondratiev EV, Abramov RV. Public relations. Textbook for higher education. Moscow: Academic project.2009.

[20] Florovsky SYu. Three-Dimensional model of effective characteristics of managerial activity: empirical validation Bulletin of the Baltic Pedagogical Academy.1997;12:95-102.

[21] Khashchenko VA. Research of the collective subject of management. Joint activity: methodology, theory, practice. 1998; $1: 88-98$

[22] Tolochek VA. Triad of management and management style. Sociological research.1992;1:121-125. 
[23] Lyashenko AI. Organization and management of social work in Russia. Moscow: Nauka. 1995.

[24] Tatarinova GN. Management of public relations: Textbook for higher education institutions. Saint Petersburg: Peter.2004.

[25] Bolotova AK, Zhukov YuM, Petrovskaya LA. Social communications. Moscow: Gardariki.2008.

[26] Doblaev VL. Organizational behavior. Moscow: EKMOS.2002. 